\title{
Review of the Tanaka Ligament in the Temporomandibular Joint. Analyzing its Scientific Validity
}

\author{
Revisión del Ligamento de Tanaka en la Articulación \\ Temporomandibular. Analizando su Validez Científica
}

\author{
Ramón Fuentes $^{1}$; Fernando Dias ${ }^{1}$; Carlos Salamanca ${ }^{1,3}$; Evelyn Borie-Echevarría ${ }^{2}$ \& Nicolás Ernesto Ottone ${ }^{1,4,5}$
}

FUENTES, R.; DIAS, F.; SALAMANCA, C.; BORIE-ECHEVARRÍA, E. \& OTTONE, N. E. Review of the tanaka ligament in the temporomandibular joint. Analyzing its scientific validity. Int. J. Morphol., 36(1):87-91, 2018.

SUMMARY: The temporomandibular joint (TMJ) is composed of bony structures, cartilage, capsule, articular disc, synovial membrane and ligaments. Some authors consider the "Tanaka ligament" described in the 1980s by Terry Tanaka as an intra-capsular ligament of the TMJ that unites medially the articular disc and mandibular fossa. The aim of the present study was to analyze the use of the term "Tanaka ligament" in the literature evaluating the scientific support of its existence. A literature review was carried out under the terms "Tanaka Ligament [AND] TMJ" and "Ligamento Tanaka [AND] ATM" (Spanish and Portuguese) in the search engines: MEDLINEPubmed, Science Direct, Google Scholar, LILACS-Bireme and SciELO. Scientific articles and theses were considered in English, Spanish and Portuguese. A total of 1,355 studies were found, summing up the results of all the search engines, of which 8 studies (5 articles and 3 theses) were selected after applying inclusion and exclusion criteria, selection by title, abstract and content. Most of these studies were discarded because they had contents related to the TMJ and/or ligaments wherein an author used the surname "Tanaka", that were not related to the Tanaka ligament. Among the 8 selected studies, 6 of them cite text books, 1 cites a video published by Terry Tanaka and 1 cites a thesis. Most of these textbooks cited also refer to videos by Terry Tanaka and his books. Moreover, most of the anatomical literature does not consider this ligament as an individualized structure. Although there are descriptions of Tanaka's ligament in textbooks, the scientific support of its existence is based only on videos and texts by Terry Tanaka. The dissemination of knowledge associated with this ligament must be cautious, as there is a need for further morphological and functional studies to confirm its existence.

KEY WORDS: TMJ; Ligaments; Tanaka ligament.

\section{INTRODUCTION}

The temporomandibular joint (TMJ) is formed by the condylar process of the mandible, the mandibular fossa and the articular tubercle of the temporal bone (Tortora \& Derrickson, 2009). It is characterized as a bilateral hinge joint that allows special movements of opening and closing of the mouth, in addition to the excursion movements of protrusion, retrusion and mandibular laterality, all of these movements are associated with the masticatory function (Drake et al., 2004).

The TMJ is one of the only movable joints of the head, along with the articulation of the ossicles of the ear, with a synovial characteristic that has its articular surfaces covered by fibrocartilage (Standring, 2008; Tortora \& Derrickson).
Among the components of TMJ are the bone portions (mandibular fossa of the temporal bone, mandibular condyle), articular cartilage, joint capsule, articular disc, synovial membrane and its ligaments (Drake et al.; Standring; Tortora \& Derrickson).

The TMJ ligaments help to limit their movements (Okenson, 2013). Among the classic extra-capsular ligaments associated with the TMJ, we can mention the temporomandibular (lateral), sphenomandibular and styloomandibular ligaments (Drake et al.; Standring; Tortora \& Derrickson; Norton, 2012; Fuentes et al., 2014). There are also the medial and lateral collateral ligaments that are intra-capsular and that connect the articular disc to the TMJ joint capsule (Norton).

${ }^{1}$ Department of Integral Adult Care, Dental Sciences Research Center. (CICO), Dental School, Universidad de La Frontera, Temuco, Chile.

${ }^{2}$ Facultad de Ciencias, Universidad Mayor, Temuco, Chile.

${ }^{3}$ Universidad Adventista de Chile, Chillán, Chile.

${ }^{4}$ Centro de Excelencia en Estudios Morfológicos y Quirúrgicos (CEMyQ), Universidad de La Frontera, Temuco, Chile.

${ }^{5}$ Laboratory of Plastination \& Anatomical Techniques, Dental Sciences Research Center. (CICO), Dental School, Universidad de La Frontera, Temuco, Chile. 
Some authors describe another intra-capsular ligament of TMJ called the Tanaka ligament (Langton \& Eggleton, 1992; Sosa, 2006; Okeson, 2013) originally described by investigator Terry Tanaka in 1980 decade (Tanaka, 1986a; Tanaka, 1986b), this ligament would unite the articular disk firmly to the wall of the mandibular fossa in the temporal bone, which favors the disc to luxate medially in case of impacts (Langton \& Eggleton; Sosa). However, the anatomical literature (Drake et al.; Dauber, 2007; Standring; Tortora \& Derrickson; Norton; Moore et al., 2014) does not consider this ligament as an individualized structure in TMJ.

The aim of the present study was to perform a literature review on the use of the Tanaka ligament, in order to seek scientific support for its existence.

\section{MATERIAL AND METHOD}

A literature review was conducted to obtain information about the Tanaka ligament in order to answer the following question: "Is the Tanaka ligament a scientifically supported structure?" The search for scientific literature identified articles identifying the anatomical structures associated with the temporomandibular joint.

\section{Selection Criteria}

Inclusive: Scientific articles and theses published in English, Spanish and Portuguese, articles that identified structures in humans, articles published between 1986 and 2017.

Exclusion: Scientific articles and theses of experimental design or quasi experimental that were realized in animals.

The selection of articles was carried out by two researchers independently; when there was controversy and differences in the application of the selection criteria, a third researcher performed the analysis and final determination for the incorporation or exclusion of the study.

Search strategy. The databases used were MEDLINEPubmed, ScienceDirect, Google Scholar, LILACS and SCieLO.

Limits were studies in humans. The search algorithms in the databases were:

- MEDLINE-Pubmed: Tanaka TT [Author] AND TMJ; Tanaka ligament AND TMJ.

- ScienceDirect: Tanaka ligament [AND] TMJ.

- Google Schoolar: Tanaka Ligament TMJ.
- Google Schoolar (Español): Ligamento Tanaka [AND] ATM.

- LILACS-Bireme: Ligamento [AND] ATM.

- SciELO: Ligamento [AND] ATM.

The search was finished with a manual review of the references of the selected articles.

\section{RESULTS}

The search strategy in the Google Scholar, MEDLINE-Pubmed, ScienceDirect, SciELO and LILACS databases found a total of 1355 items associated with the searched terms, of which only 5 articles and 3 theses met the selection criteria applied.

The items obtained using the terms used in each database are presented in Table I.

Table II lists the articles and theses found in the search results performed in the databases described previously, associating the description and the reference associated with the Tanaka ligament.

\section{DISCUSSION}

In the present study, a review was performed to evaluate the use of the term "Tanaka Ligament" in scientific literature, focusing on its description and interpretation, as well as reviewing which sources the authors of the studies found used to support the concept of this ligament.

The name of this structure is due to the researcher Terry Tanaka, who pioneered the description and individualization of this ligament in the medial region internally of the TMJ joint capsule, through a series of dissection videos (Tanaka, 1986a; Tanaka, 1988; Tanaka, 1992).

The eponymy applied to this ligament associated with the name of the researcher Terry Tanaka can be understood as a problem, since the International Anatomical Terminology (Federative Committee on Anatomical Terminology, 2011), which regulates and standardizes the anatomical terms, seeks to eliminate structures named by eponyms. The tendency to eliminate eponyms is justified by the lack of relationship of the structure name with its shape, location and function, as it happens with most anatomical structures described. 
Table I. Results obtained in each database for the "Tanaka Ligament".

\begin{tabular}{lll}
\hline Database & Founded items & Selected Items \\
\hline MEDLINE-Pubmed & 9 & 0 \\
Science Direct & 103 & 1 article \\
Google Scholar & 1150 & 2 articles $(1$ repeated $)$ \\
Google Scholar (Spanish) & 72 & 3 articles; 3 theses \\
LILACS-Bireme & 17 & 0 \\
SciELO & 4 & 0 \\
\hline TOTAL & 1355 & 8 (5 articles, 3 theses $)$ \\
\hline
\end{tabular}

Table II. Description of the Tanaka Ligament in the results found associated with the item's database and its source.

\begin{tabular}{|c|c|c|c|}
\hline Author/Year & Database & Source & Description of the Tanaka Ligament / Reference \\
\hline $\begin{array}{ll}\text { Fanghänel } & \& \\
\text { Gedrange, 2007 } & \end{array}$ & $\begin{array}{l}\text { Google Scholar / } \\
\text { S cience Direct }\end{array}$ & Ann. Anat. & $\begin{array}{l}\text { - String-shaped reinforcement of the medial capsule } \\
\text { (Tanaka, 1986a). }\end{array}$ \\
\hline Cuccia et al., 2011 & Google Scholar & $\begin{array}{l}\text { J. Am. Osteopath. } \\
\text { Assoc., }\end{array}$ & - Only cites as an TMJ ligament (Williams et al., 1989). \\
\hline Fuentes et al., 2015 & Google Scholar (ESP) & Int. J. Morphol., & $\begin{array}{l}\text { - It joins disc with the cranial articular surface (Sosa, } \\
\text { 2006). } \\
\text { - The upper portion of the bilaminar zone of the } \\
\text { articular disc is inserted in the posterior zone of the } \\
\text { fossa, superior to the area of the petrotympanic fissure } \\
\text { (Langton \& Eggleton, 1992). }\end{array}$ \\
\hline Fuentes et al., 2016 & Google Scholar (ESP) & Int. J. Morphol., & $\begin{array}{l}\text { - Ligament extending from the articular disc, medially } \\
\text { and anteriorly, inserted into the inferome dial zone of } \\
\text { the mandibular fossa. } \\
\text { - Originally considered a medial fascicle of the medial } \\
\text { collateral ligament. } \\
\text { - Reinforcing the articular disc medially, contributing to } \\
\text { form a medial reinforcing arch, around rotation during } \\
\text { opening and buccal closure (Langton \& Eggleton, } \\
\text { 1992). }\end{array}$ \\
\hline $\begin{array}{l}\text { Fuentes \& Ottone, } \\
2017\end{array}$ & Google Scholar (ESP) & Int. J. Morphol., & $\begin{array}{l}\text { - Ligament located anterior to TMJ, and extending from } \\
\text { the articular disc to the mandibular fossa (Langton \& } \\
\text { Eggleton, 1992; Fuentes et al., 2016). }\end{array}$ \\
\hline Garcia, 2008 & Google Scholar (ESP) & $\begin{array}{l}\text { Thesis/Escuela de } \\
\text { Osteopatia de Madrid }\end{array}$ & $\begin{array}{l}\text { - It joins the articular disk to the superior bone surface, } \\
\text { which favors the disc luxation medially in case of } \\
\text { impact (Sosa, 2006). }\end{array}$ \\
\hline Osma López, 2014 & Google Scholar (ESP) & $\begin{array}{l}\text { Thesis/ Universitat de } \\
\text { Lérida }\end{array}$ & $\begin{array}{l}\text { - Ligament is related to the disc in its antero medial } \\
\text { part. This ligament is much more resistant than the } \\
\text { collaterals, therefore promoting its dislocation } \\
\text { anteromedially (Okeson, 1989). }\end{array}$ \\
\hline $\begin{array}{l}\text { Torres-Pazmiño, } \\
2016\end{array}$ & Google Scholar (ESP) & $\begin{array}{l}\text { Thesis / Universidad } \\
\text { Central del Ecuador }\end{array}$ & $\begin{array}{l}\text { - Temporodiscal ligament. It extends from the medial } \\
\text { pole of the disc, backwards and inwards, to the medial } \\
\text { pole of the frontal region. It limits the anterolateral } \\
\text { movement of the articular disc (Giambartolomei, } \\
\text { 2005). }\end{array}$ \\
\hline
\end{tabular}

It is common for definitions of Tanaka's ligament to be accompanied by a brief explanation of the reason for its name, which adds no value to the structure. Only one study (Torres Pazmiño, 2016) presented an alternative for the use of this eponymy, naming it "temporodiscal ligament". However, the term temporodiscal is still broad and imprecise, as it would cover the temporal bone and the articular disc completely, thus making it difficult to relate to an intracapsular ligament in the medial region of the articular disc.
The scientific validity of the existence of the Tanaka ligament is controversial, as has been reported in previous studies (Sato et al., 1995; Fuentes \& Ottone, 2017). This structure may be considered a part of the medial collateral ligament (Fuentes et al., 2016). Among the eight studies selected in this review that recognize the Tanaka ligament as an individualized structure, six of them (Garcia, 2008; Cuccia et al., 2011; Osma López, 2014; Fuentes et al., 2015; Fuentes et al., 2016; Fuentes \& Ottone) refer basically to 
textbooks (Langton \& Eggleton; Okeson 1989; Williams et al., 1989; Sosa) as a scientific basis; one study (Fanghänel \& Gedrange, 2007) cites a dissection video published by Terry Tanaka (1986a) and another study (Torres-Pazmiño) cites a thesis (Giambartolomei, 2005). These text books (Langton \& Eggleton; Sosa) also use Terry Tanaka's videos (Tanaka, 1986a; Tanaka 1988) to support the existence of this ligament.

Among the textbooks cited, only the Gray's Anatomy (Williams et al.) is a book of anatomical literature, however new editions of this same book (Drake et al.; Standring) no longer contain the description of this ligament. However, Okeson's book "Management of Temporomandibular Disorders and Occlusion" (Okeson, 2013) still recognizes this structure, however does not name it directly as "Tanaka Ligament" describing it as "an intracapsular ligament of the medial TMJ described by Terry Tanaka" whose reference is also due to a video (Tanaka, 1992) and a book by Terry Tanaka (Tanaka, 1989).

The studies of TMJ found by authorship and coauthorship of Terry Tanaka (Tanaka, 1986b; McNeill et al., 1990; Schwaighofer et al., 1990) have never used the term "Tanaka Ligament" to refer to this alleged ligament in special.

The vast majority of the more than 1,300 studies found in the databases we surveyed were discarded for having some of the authors with Tanaka surnames who studied structures of the TMJ or ligaments in general, unrelated to the structure in question. It is noteworthy that in some studies about the TMJ there were researchers whose name was spelled as "T. Tanaka " (Tanaka et al., 2002; Yamaza et al., 2003), but that it was not Terry Tanaka.

The present study is in full agreement with the earlier study carried out 22 years ago by Sato et al., that reported although there are conventional descriptions of TMJ ligaments in textbooks, there is still controversy and unanswered questions about their existence (Fuentes \& Ottone). Since the anatomical and functional information of the Tanaka ligament is insufficient, heterogeneous and imprecise, it reveals the need for morphological and functional studies in a significant number of cadaveric samples.

Thus, it is concluded that the diffusion of the existence of this TMJ ligament should be carried out cautiously, especially in scientific literature and also in classes for students of all levels, until their existence, function and prevalence are confirmed by appropriate scientific studies.
FUENTES, R.; DIAS, F.; SALAMANCA, C.; BORIEECHEVARRÍA, E. \& OTTONE, N. E. Revisión del ligamento de tanaka en la articulación temporomandibular. Analizando su validez científica. Int. J. Morphol., 36(1):87-91, 2018.

RESUMEN: La articulación temporomandibular (TMJ) se compone de estructuras óseas, cartílago, cápsula, disco articular, membrana sinovial y ligamentos. Algunos autores consideran el "ligamento de Tanaka" descrito en los años 80 por Terry Tanaka como un ligamento intra-capsular de la ATM que une medialmente el disco articular y la fosa mandibular. El objetivo del presente estudio fue analizar el uso del término "ligamento de Tanaka" en la literatura evaluando el soporte científico de su existencia. Se realizó una revisión de la literatura bajo los términos "Tanaka Ligament [AND] TMJ" y "Ligamento Tanaka [AND] ATM" (Español y Portugués) en los buscadores: MEDLINE-Pubmed, Science Direct, Google Académico, LILACS-Bireme y SciELO. Se consideraron artículos científicos y tesis en inglés, español y portugués. Se obtuvieron un total de 1.355 estudios, sumando los resultados de todos los motores de búsqueda, de los cuales se seleccionaron 8 estudios (5 artículos y 3 tesis) después de aplicar los criterios de inclusión y exclusión y la selección por título, resumen y contenido. La mayoría de estos estudios fueron descartados porque tenían contenidos relacionados con la ATM y/o ligamentos cuyo autor tenía el apellido "Tanaka", que no estaba relacionado con el ligamento de Tanaka. Entre los 8 estudios seleccionados, 6 de ellos citan libros de texto, uno cita un video publicado por Terry Tanaka y otro cita una tesis. La mayoría de estos libros citados también se refieren a los videos de Terry Tanaka y sus libros. Además, la mayor parte de la literatura anatómica no considera este ligamento como una estructura individualizada. Aunque hay descripciones del ligamento de Tanaka en los libros de texto, el apoyo científico de su existencia se basa sólo en videos y textos de Terry Tanaka. La difusión del conocimiento asociado a este ligamento debe ser cautelosa, revelando la necesidad de más estudios morfológicos y funcionales para confirmar su existencia.

PALABRAS CLAVE: ATM; Ligamentos; Ligamento de Tanaka.

\section{REFERENCES}

Cuccia, A. M.; Caradonna, C. \& Caradonna, D. Manual therapy of the mandibular accessory ligaments for the management of temporomandibular joint disorders. J. Am. Osteopath. Assoc., 111(2):10212, 2011.

Dauber, W. Pocket Atlas of Human Anatomy. Founded by Heinz Feneis. $5^{\text {th }}$ ed. Stuttgart, Thieme, 2007.

Drake, R. L.; Vogl, A. W. \& Mitchell, A. W. Gray's Anatomy for Students. Philadelphia, Churchill Livingstone, 2004.

Fanghänel, J. \& Gedrange, T. On the development, morphology and function of the temporomandibular joint in the light of the orofacial system. Ann. Anat., 189(4):314-9, 2007.

Federative Committee on Anatomical Terminology. Terminologia Anatomica. International Anatomical Terminology. Stuttgart, Georg Thieme Verlag, 2011.

Fuentes, R. \& Ottone, N. E. Proposal on inclusion and elimination of anatomical terms in Terminologia Anatomica corresponding to the 
temporomandibular joint. Int. J. Morphol., 35(1):12-5, 2017.

Fuentes, R.; Bucchi, C. \& Cantín, M. A study of terms used in scientific literature to refer to the extracapsular ligaments of the temporomandibular joint. Part I: Ligamentum sphenomandibulare. Int. J. Morphol., 32(3):9816, 2014.

Fuentes, R.; Cantín, M.; Ottone, N. E. \& Bucchi, C. Characterization of bone components of the temporomandibular joint. A literature review. Int. J. Morphol., 33(4):1569-76, 2015.

Fuentes, R.; Ottone, N. E.; Bucchi, C. \& Cantín, M. Analysis of terms used in the literature to refer to temporomandibular joint capsule and joint ligaments. Int. J. Morphol., 34(1):342-50, 2016.

Garcia, C. G. Validación del Test de Movilidad Mandibular Comparado con Tomografía Computarizada. Thesis. Madrid, Escuela de Osteopatia de Madrid, 2008.

Giambartolomei, L. A. Estudio Anatómico y Dimensional del Disco del Complejo Articular Temporomandibular. PhD Thesis. Córdoba, Universidad Nacional de Córdoba, 2005.

Langton, D. P. \& Eggleton, T. M. Functional Anatomy of the Temporomandibular Joint Complex. Santiago de Chile, Inforc Publications, 1992.

Moore, K. L.; Dalley, A. F. \& Agur, A. M. R. Clinically Oriented Anatomy. $7^{\text {th }}$ ed. Philadelphia, Wolters Kluwer Health/Lippincott Williams \& Wilkins, 2014.

Norton, N. S. Netter's Head and Neck Anatomy for Dentistry. $2^{\text {nd }}$ ed. Philadelphia, Elsevier/Saunders, 2012.

Okeson, J. P. Management of Temporomandibular Disorders and Occlusion. $2^{\text {nd }}$ ed. St. Louis, Mosby, 1989.

Okeson, J. P. Management of Temporomandibular Disorders and Occlusion. $7^{\text {th }}$ ed. St. Louis, Elsevier/Mosby, 2013.

Osma López, B. Eficacia de la Terapia y/o los Ejercicios Terapéuticos en Pacientes con Trastorno Temporomandibular. Alteración cóndilo-discal posterior. Bachelor's Thesis. Lérida, Universitat de Lérida, 2014.

Sato, H.; Ström, D. \& Carlsson, G. E. Controversies on anatomy and function of the ligaments associated with the temporomandibular joint: a literature survey. J. Orofac. Pain, 9(4):308-16, 1995.

Sosa, G. E. Detección Precoz de los Desórdenes Témporomandibulares. Caracas, Amolca, 2006.

Standring, S. Gray's Anatomy: The Anatomical Basis of Clinical Practice. $40^{\text {th }}$ ed. Edinburgh, Churchill-Livingstone/Elsevier, 2008.

Tanaka T. T. A rational approach to the differential diagnosis of arthritic disorders. J. Prosthet. Dent., 56(6):727-31, 1986 b.

Tanaka, T. T. Advanced Dissection of the Temporomandibular Joint. Videotape. Instruction video, T. T. Tanaka, 1988.

Tanaka, T. T. Dissection of the Head, Neck, and Temporomandibular Joint. Videotape. Instruction video, T. T. Tanaka, 1986a.

Tanaka, T. T. Head, Neck and TMD Management. $4^{\text {th }}$ ed. San Diego, Clinical Research Foundation, 1989.

Tanaka, T. T. TMJ Microanatomy: An Anatomical Approach to Current Controversies. A Teaching Videotape. Videotape. Chula Vista, T. T. Tanaka, 1992.

Tanaka, T.; Morimoto, Y.; Masumi, S.; Tominaga, K. \& Ohba, T. Utility of frequency-selective fat saturation T2-weighted MR images for the detection of joint effusion in the temporomandibular joint. Dentomaxillofac. Radiol., 31(5):305-12, 2002.

Torres-Pazmiño, D. P. Comportamiento de la Articulación Temporomandibular en Hipermovilidad Condilar, Estudio de los Niveles Tensionales producidos en Huesos, Disco y Ligamentos, por Medio de Elementos Finitos. M.Sc. Thesis. Quito, UCE, 2016.

Tortora, G. J. \& Derrickson, B. H. Principles of Anatomy and Physiology. $12^{\text {th }}$ ed. Hoboken, John Wiley \& Sons, 2009.

Williams, P. L.; Warwick, R.; Dyson, M. \& Bannister L. H. Gray's Anatomy. $37^{\text {th }}$ ed. Edinburgh, Churchill Livingstone, 1989.

Yamaza, T.; Masuda, K. F.; Tsukiyama, Y.; Nishijima, K.; Murakami, R.; Kido, M. A.; Koyano, K. \& Tanaka, T. NF-kappaB activation and iNOS expression in the synovial membrane of rat temporomandibular joints after induced synovitis. J. Dent. Res., 82(3):183-8, 2003.

\author{
Corresponding author: \\ Dr. Ramón Fuentes Fernández \\ Department of Integral Adult Care \\ Dental Sciences Research Center (CICO) \\ Dental School, Universidad de La Frontera \\ Av. Francisco Salazar 01145 \\ Box 54-D \\ Temuco \\ CHILE
}

Email: ramon.fuentes@ufrontera.cl

Received: 31-07-3027

Accepted: 13-10-2017 